\title{
Polydioxanone as Buried Suture in Facial Trauma - A Prospective Study
}

\author{
Pinki Pargal ${ }^{1}$ \\ ${ }^{1}$ Department of Plastic Surgery, Christian Medical College, Ludhiana, Punjab, India.
}

\section{ABSTRACT}

\section{BACKGROUND}

Irrespective of cause of injury, facial scars are always considered as a stigma causing both mental and social disgrace to the victim. The principle aim of any suturing is to produce aesthetically pleasing scar. Besides surgical skills, the choice of suture material also plays a very important role in getting a good scar. Though suture material used for suturing is mostly Nylon everywhere, it's the buried sutures which obliterate the dead space and reduce wound tension which make the real difference in the appearance of scar. Sutures of different types are today available \& the operating surgeon uses the best suture material for the patient in a given circumstance based on his personal experience, scientific observations, \& manufacturer's advice. ${ }^{1}$

\section{METHODS}

This is a prospective study conducted in the department of plastic surgery at Christian Medical College, Ludhiana from May 2012 to April 2013. The study included all the patients of facial trauma registered during that period of one year. Demographic profile was noted along with the cause of trauma. A well-informed consent was taken. In our study skin approximation was done by either 5-0 or 6-0 Nylon suture. Buried suture used in all was Polydioxanone (PDS) 5-0. Skin sutures were removed on $5^{\text {th }}$ POD. Beusang Clinical Scar assessment scale ${ }^{2}$ was used in the study to assess scar appearance. Patients were followed every month for 5 months after removal of skin sutures. The parameters noted included, colour, contour, matte/shine, and texture of scar. Photographic record of the patients was maintained. Statistical analysis was done using McNemar test.

\section{RESULTS}

Out of the 40 patients in our study, road traffic accidents constituted 85 percent of facial trauma, rest included fall on floor. M:F ratio was 3:1. With Polydioxanone as buried suture, 35 patients (87.5\%) had normal texture, 30 patients (75\%) had Matte appearance of the scar, 20 patients (50\%) had no distortion of scar, 25 patients $(62.5 \%)$ had perfect match of colour with hypertrophic scar noticed in 4 patients $(0.1 \%)$.

\section{CONCLUSIONS}

Polydioxanone as buried suture gave aesthetically pleasing scar which improved in appearance during the follow up periods. There was significant statistical improvement in scar appearance starting from $5^{\text {th }}$ day of suture removal to assessment at 5 months. No discharge from the wound site was noted in any of the patients. Hypertrophic scars noticed were later treated with steroid injections.

\section{KEY WORDS}

Facial Suturing, Polydioxanone Buried Suture, Beusang Clinical Scar Assessment Scale

\author{
Corresponding Author: \\ Dr. Pinki Pargal, \\ Professor of Plastic Surgery, \\ Christian Medical College, \\ Ludhiana, Punjab, India. \\ E-mail: pinkipargal@gmail.com
}

DOI: $10.14260 / \mathrm{jemds} / 2020 / 457$

How to Cite This Article:

Pargal P. Polydioxanone as buried suture in facial trauma - a prospective study. J. Evolution Med. Dent. Sci. 2020;9(30): 20932096, DOI: $10.14260 /$ jemds/2020/457

Submission 23-04-2020,

Peer Review 16-06-2020,

Acceptance 24-06-2020,

Published 27-07-2020.

Copyright (C) 2020 JEMDS. This is an open access article distributed under Creative Commons Attribution License [Attribution 4.0 International (CC BY 4.0)] 


\section{BACKGROUND}

Irrespective of cause of injury, facial scars are always considered as a stigma causing both social \& mental trauma. The formation of scars is influenced by many exogenous and endogenous factors among which the type of suture material used is of utmost importance 3 . There are large number of suture materials available, but a surgeon tries to choose the best suture material for their patients depending upon their clinical experience. Today surgeons are convinced that the quality of scar is affected by the type of suture used. Besides epidermal sutures, buried sutures also play important role in the appearance of scars as these sutures reduces the wound tension, obliterate the dead space and support the wound even after the removal of epidermal sutures. ${ }^{4}$ Many studies have been conducted in an effort to search the ideal suture material which included both synthetic, non-synthetic, absorbable \&non-absorbable sutures. At present, no single wound closure material fulfills all the qualities of an ideal material and therefore there is ongoing search for best suture materials. A large number of suture materials have emerged in the last fifty years that differ in physical and biological properties and even today there is a search for an ideal suture material. No definite consensus has been reached to designate a particular suture material an ideal suture as all the criteria for an ideal suture material is not fulfilled by any particular suture. The choice of suture also depends on its tensile strength, non-allergenic and healing characteristics. In some patients the choice of suture is also restricted because of the financial status of the patient as some sutures are costly in comparison to many other cheap sutures. ${ }^{5}$ Most widely used sutures as buried sutures include Natural sutures like plain catgut or Chromic catgut. Synthetic sutures include Polyglactin 910, Polydioxanone, Polyglyconate which vary in their physical characteristics. ${ }^{6}$ Besides sutures many exogenous factors also play an important role in final appearance of scar which include the nutritional status of the patient. A lack of carbohydrates, proteins, zinc, vitamins can cause delay in wound healing. Immuno compromise are more susceptible to infection. Patients on steroids or any chemotherapy have poor immune response. Some patients are allergic to certain suture materials and exhibit a heightened immune response or allergic reaction so it's mandatory time take a thorough history of patients to detect any allergic reactions previously. ${ }^{7}$

The basic principles of wound management remain same in all circumstances which include to avoid wound infection, assist in hemostasis and to provide an aesthetically pleasing and functionally acceptable scar. ${ }^{8}$ All those wounds which require suturing need thorough assessment whether the wound requires only skin sutures or buried sutures also. Because placement of buried sutures is also an art. Normally these sutures gets absorbed by inflammation, enzymatic degradation or hydrolysis and if these sutures are placed too superficially they may get transdermally eliminated from the wound thus compromising the final appearance of the scar. ${ }^{9}$ So buried sutures are to be selected with utmost caution based on their physical properties and of course the experience of the surgeon. Many comparative studies have been conducted to search for an ideal buried suture. Polydioxanone is one such absorbable synthetic suture which is monofilament composed of polyester, poly (p-dioxanone). Its absorption is reliable and predictable at 180 days by hydrolysis. It has prolonged tensile strength and good for high tension areas and contaminated wounds. It has minimum tissue reaction which makes this suture preferable in suturing. ${ }^{5}$ The prospective study was conducted in the department of plastic surgery of Christian medical college Ludhiana from May 2012 to April 2013 with an aim to study the appearance of scar after the use of Polydioxanone suture as buried suture.

\section{METHODS}

The prospective study was done for a period of one year after taking clearance from the institutional ethics clearance committee. It included all patients between the age of 3 years to 70 years who presented with facial trauma in the emergency department and needed suturing of wound. In all patients, epidermal skin suturing was done with 5-0 Nylon suture or Nylon $6-0$ suture and buried suture used in all patients was Polydioxanone 5-0. Exclusion criteria included 1) all those injuries where there was associated fractures of the facial bones. 2) Patients with burns 3) facial injuries with abrasions 4) patients with any comorbidities like diabetes, hypertension or previous chemotherapy 5) Lacerations less than $1 \mathrm{~cm}$ in size or greater than $6 \mathrm{~cm}$. 6) Contaminated wound. A detailed history which included demographic profile and cause of trauma was noted. Any associated injuries were also noted. A written informed consent was taken from the patients and in case of children consent was taken from the parents in their vernacular language. Patients were clearly conveyed in their vernacular language that a particular suture will be used as buried suture among the other available sutures \& that photographic records will be maintained with the same camera with same lighting \& settings which in our study included SLR camera with aperture 5.6, speed 125 in indoor set up of outpatient department of plastic surgery. The follow up visits monthly for 5 months was conveyed to the participants. The cost of suture was also conveyed to them, once eligible patients gave the consent, patients were enrolled in the study. The epidermal suturing was done by 5-0 nylon /6-0 Nylon. The buried suture used in our study was Polydioxanone 5-0. Prior to suturing wound was prepared with $10 \%$ povidone iodine. Draping was done with sterile sheets. Local anesthesia which included 2\% Xylocaine or General Anesthesia were used as per the individual requirement. After wound closure, wound was covered with sterile Steristrip ${ }^{10}$. On $5^{\text {th }}$ postoperative day epidermal skin sutures were removed. The Evaluation of Cosmetic appearance of scar was done monthly up to 5 months based on Beusang E Scale ${ }^{2}$. The visual appearance of the scar on the basis of colour, contour, distortion, texture, Matte/Shine (presence or absence of redness). The scores given were 1 for perfect match, 2 for slight mismatch, 3 for gross mismatch. In Texture assessment score of 1 was given when it matched normal skin completely, score 2 was given. When scar was just palpable and score 3 if it was firm in feel. Similarly, in Contour assessment scar was given score 1 if it flushed with the normal Skin, Score 2 was given for slightly raised or indented scar and score 3 for hypertrophic scar. Distortion parameter was assessed with score 1 when there was no distortion of the scar, score 2 for mild distortion and score 3 for moderate distortion 
and score 4 for Severe distortion. Matte appearance of the scar was given score 1 and Shine/redness in scar was given Score of 2. The hypertrophic scars were excised and sent for histopathological examination for conformation. Photographic record of the patients was kept.

\section{Statistical Analysis}

The categorical variables were represented as count (percentage) and continuous variable as Mean \pm SD. McNemar test was used to compute the change in colour match, contour, matte or shine, distortion and texture at from 1 month to 5 months. The $\mathrm{p}$ value $<0.05$ was considered significant. All statistical analysis was performed using SPSS (Statistical Packages for Social Sciences, version 21.0. Armonk, NY: IBM corp.).

\section{RESULTS}

\begin{tabular}{|c|c|c|c|c|c|c|}
\hline & $\begin{array}{c}\text { Cosmetic } \\
\text { Visual } \\
\text { Assessment }\end{array}$ & $\begin{array}{c}1^{\text {st }} \\
\text { Month }\end{array}$ & $\begin{array}{c}2^{\text {nd }} \\
\text { Month }\end{array}$ & $\begin{array}{c}3^{\text {rd }} \\
\text { Month }\end{array}$ & $\begin{array}{c}4^{\text {th }} \\
\text { Month }\end{array}$ & $\begin{array}{c}5^{\text {th }} \\
\text { Month }^{*}\end{array}$ \\
\hline \multirow{3}{*}{$\begin{array}{l}\text { Colour } \\
\text { Match }\end{array}$} & Perfect & 0 & 0 & $\begin{array}{c}5 \\
(12.5 \%)\end{array}$ & $\begin{array}{c}5 \\
(12.5 \%)\end{array}$ & $\begin{array}{c}25 \\
(62.5 \%)\end{array}$ \\
\hline & $\begin{array}{l}\text { Slight or Gross } \\
\text { mismatch }\end{array}$ & $\begin{array}{c}40 \\
(100 \%)\end{array}$ & $\begin{array}{c}40 \\
(100 \%)\end{array}$ & $\begin{array}{c}35 \\
(87.5 \%)\end{array}$ & $\begin{array}{c}35 \\
(87.5 \%)\end{array}$ & $\begin{array}{c}15 \\
(37.5 \%)\end{array}$ \\
\hline & & $\begin{array}{c}1^{\text {st }} \\
\text { Month }\end{array}$ & $\begin{array}{c}2^{\text {nd }} \\
\text { Month }^{*}\end{array}$ & $\begin{array}{c}3^{\text {rd }} \\
\text { Month }^{*}\end{array}$ & $\begin{array}{c}4^{\text {th }} \\
\text { Month }^{*}\end{array}$ & $\begin{array}{c}5^{\text {th }} \\
\text { Month }^{*}\end{array}$ \\
\hline \multirow{4}{*}{ Contour } & Flushed with & 14 & 20 & $\begin{array}{c}20 \\
(50 \%)\end{array}$ & $\begin{array}{c}20 \\
50 \%\end{array}$ & $\begin{array}{c}23 \\
(57.5 \%)\end{array}$ \\
\hline & $\begin{array}{l}\text { N SkIn } \\
\text { Slightly Raised }\end{array}$ & $\begin{array}{c}(35 \%) \\
26\end{array}$ & 20 & $\begin{array}{c}(30 \%) \\
20\end{array}$ & 20 & 17 \\
\hline & or Hypertrophic & $\begin{array}{c}(65 \%) \\
1^{\text {st }}\end{array}$ & $\begin{array}{c}(50 \%) \\
2^{\text {nd }}\end{array}$ & $\begin{array}{c}(50 \%) \\
3^{\text {rd }}\end{array}$ & $\begin{array}{l}(50 \%) \\
4^{\text {th }}\end{array}$ & $\begin{array}{c}(42.5 \%) \\
5^{\text {th }}\end{array}$ \\
\hline & & Month & Month* & Month & Month* & Month $^{*+}$ \\
\hline \multirow{2}{*}{$\begin{array}{l}\text { Matte or } \\
\text { Shine }\end{array}$} & Matte & $20(50 \%)$ & $30(75 \%)$ & $20(50 \%)$ & $30(75 \%)$ & $30(75 \%)$ \\
\hline & Shine & $20(50 \%)$ & $10(25 \%)$ & $20(50 \%)$ & $10(25 \%)$ & $10(25 \%)$ \\
\hline \multicolumn{7}{|c|}{ Table 1. PDS Suture } \\
\hline & & & & & & \\
\hline
\end{tabular}

\begin{tabular}{|c|c|c|c|c|c|c|}
\hline \multirow{3}{*}{$\begin{array}{c}\text { Cosmetic } \\
\text { Assessment }\end{array}$} & \multicolumn{6}{|c|}{ Follow Up } \\
\hline & & $1^{\text {st }}$ & $2^{\text {nd }}$ & $3^{\text {rd }}$ & $4^{\text {th }}$ & $5^{\text {th }}$ \\
\hline & & Month & Month & Month & Month* & Month* \\
\hline \multirow{6}{*}{ Distortion } & None to Mild & $\begin{array}{c}40 \\
(100 \%)\end{array}$ & $\begin{array}{c}36 \\
(90 \%)\end{array}$ & $\begin{array}{c}36 \\
(90 \%)\end{array}$ & $\begin{array}{c}30 \\
(75 \%)\end{array}$ & $\begin{array}{c}30 \\
(75 \%)\end{array}$ \\
\hline & $\begin{array}{l}\text { Moderate to } \\
\text { Severe }\end{array}$ & 0 & $\begin{array}{c}4 \\
(10 \%)\end{array}$ & $\begin{array}{c}4 \\
(10 \%)\end{array}$ & $\begin{array}{c}10 \\
(25 \%)\end{array}$ & $\begin{array}{c}10 \\
(25 \%)\end{array}$ \\
\hline & & $\begin{array}{c}1^{\text {st }} \\
\text { Month }\end{array}$ & $\begin{array}{c}2^{\text {nd }} \\
\text { Month }^{*}\end{array}$ & $\begin{array}{c}3^{\text {rd }} \\
\text { Month }^{*}\end{array}$ & $4^{\text {th }}$ Month & $\begin{array}{c}5^{\text {th }} \\
\text { Month }^{*}\end{array}$ \\
\hline & None & $\begin{array}{c}14 \\
(35 \%)\end{array}$ & $\begin{array}{c}20 \\
(50 \%)\end{array}$ & $\begin{array}{c}20 \\
(50 \%)\end{array}$ & $\begin{array}{c}15 \\
(37.5 \%)\end{array}$ & $\begin{array}{c}20 \\
(50 \%)\end{array}$ \\
\hline & Mild to Severe & $\begin{array}{c}26 \\
(65 \%)\end{array}$ & $\begin{array}{c}20 \\
(50 \%)\end{array}$ & $\begin{array}{c}20 \\
(50 \%)\end{array}$ & $\begin{array}{c}25 \\
(62.5 \%)\end{array}$ & $\begin{array}{c}20 \\
(50 \%)\end{array}$ \\
\hline & & $\begin{array}{c}1^{\text {st }} \\
\text { Month }\end{array}$ & $\begin{array}{c}2^{\text {nd }} \\
\text { onth }^{*}\end{array}$ & $\begin{array}{c}3^{\text {rd }} \\
\text { Month }\end{array}$ & $\begin{array}{c}4^{\text {th }} \\
\text { Month }^{*}\end{array}$ & $\begin{array}{c}5^{\text {th }} \\
\text { Month }^{*}\end{array}$ \\
\hline \multirow{2}{*}{ Texture } & Normal & $\begin{array}{c}20 \\
(50 \%)\end{array}$ & $\begin{array}{c}30 \\
(75 \%)\end{array}$ & $\begin{array}{c}30 \\
(75 \%)\end{array}$ & $\begin{array}{c}30 \\
(75 \%)\end{array}$ & $\begin{array}{c}38 \\
(95 \%)\end{array}$ \\
\hline & $\begin{array}{l}\text { Just Palpable } \\
\text { or Firm }\end{array}$ & $\begin{array}{c}20 \\
(50 \%)\end{array}$ & $\begin{array}{c}10 \\
(25 \%)\end{array}$ & $\begin{array}{c}10 \\
(25 \%)\end{array}$ & $\begin{array}{c}10 \\
(25 \%)\end{array}$ & $\begin{array}{c}2 \\
(5 \%)\end{array}$ \\
\hline \multicolumn{7}{|c|}{ Table 2. PDS Suture } \\
\hline 0.05 from 1 & 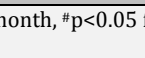 & & & & & \\
\hline
\end{tabular}

A total of 40 patients were enrolled in the study. The Mean \pm SD age of the patients was $27 \pm 17.6$ years [range $(2-65$ years)] and Male to female ratio was M:F 3:1. Facial trauma following Road traffic accident constituted 34 patients (85\%),3 patients had history of fall from bed and rest 3 patients had history of skid in bathroom.

In cosmetic visual assessment the patients with scars having perfect colour match increased significantly from none to $62.5 \%$ ( $p<0.001)$, the significant change was observed in $5^{\text {th }}$ month compared to previous months. $65 \%$ of the patients had slightly raised or hypertrophic scars. Contour which significantly reduced to $50 \%$ at $2^{\text {nd }}, 3^{\text {rd }}$ and $4^{\text {th }}$ month and $42.5 \%$ at $5^{\text {th }}$ month. The proportion of Scars with matte look was significantly increased from $50 \%$ to $75 \%$ at $2^{\text {nd }}, 4^{\text {th }}$ and $5^{\text {th }}$ month but no change was seen in $3^{\text {rd }}$ month. (Table 1)

In cosmetic assessment the patients with scars having moderate to severe distortion was seen to be increased significantly from $0 \%$ to $25 \%$ at $4^{\text {th }}$ and $5^{\text {th }}$ month but no change was seen at $2^{\text {nd }}$ and $3^{\text {rd }}$ month. The patients with scars having normal texture was significantly increased from $50 \%$ to 75 at $2^{\text {nd }}, 3^{\text {rd }}$ and $4^{\text {th }}$ month and $95 \%$ at $5^{\text {th }}$ month. (Table 2 )

\section{DISCUSSION}

In our study Male: Female ratio was 3: 1, similar results were seen in study done by M. Qui et al (2017) ${ }^{11}$ where there was male predominance. Similar results were seen in study done by M. Elarbi (2017).12 where M: F ratio was 7:1. In our study Road traffic accident constituted $85 \%$ of cause of facial trauma similar results were seen by M. Elarbi (2017) ${ }^{12}$ but this was in contrast with the study done by M. Qui et al (2017) ${ }^{11}$ where Road traffic accident constituted only $14.9 \%$, and maximum number of patients had history of fall. Our study matched the study done by M. Qui et al (2017) ${ }^{11}$ where young adults were found to be more affected compared to old age. In our study $85 \%$ of patients were in the age group of $20 \_45$ years of age. The assessment of cosmetic appearance of scar in our study with Polydioxanone as buried suture was done using Beusang E clinical assessment scale which included observation of colour, contour (scar flushed with skin or raised), and distortion (width) texture and matte/shine appearance of scar in comparison to the rest of normal skin. In our study it was observed that at 5 months of follow up period there was improvement of colour match with the surrounding skin. 25 patients $(62.5 \%)$ had perfect match with the surrounding skin giving cosmetically pleasing scar, only 10 patients which constituted $25 \%$ of the total had slight mismatch but it was acceptable to the patients. Gross mismatch was seen in only 5 patients which needed scar revision at later date. Similar results were seen in study done by Deepti et al (2018) ${ }^{13}$ where improved outcome of scar appearances seen using Polydioxanone suture material, scars showed less distortion, better quality in terms of colour and texture when compared with polyglactin 910 suture. In our study Contour of the scar also showed improvement with time with $57.3 \%$ of the total patients had scars flushed with the normal skin. Only 4 patients $(10 \%)$ had hypertrophic scar observed at 3 months follow up. Similar results were seen by Hohenleutner U et al $(2000)^{14}$ with hypertrophic scars about $10.1 \% .75 \%$ of the patient had Matte finish of the scar giving it more pleasing \& aesthetically acceptable look. Only 10 patients out of 40 had shine appearance due to some erythema. In our study 50\% (20 patients) had no distortion of the scar, there was no increase in width from its natural suture line, and however 5 patients had severe distortion which was grossly visible. Similar results were seen by study done by B. Guyuron et al (1996) ${ }^{15}$ where 3 out of 38 incision closed with PDS revealed Scar Spread (distortion) with hypertrophy in three patients. However no statistically significant difference in quality of scar was seen when colour and texture was compared between polyglactin 
910 and Polydioxanone suture. None of our patient showed any discharge from the suture site or stitch abscess proving infection rate less with this suture. This is in comparable to the studies done by Sanz et al (1988) ${ }^{16}$ and Bhargava et al ${ }^{17}$ where Polydioxanone suture elicited minimal inflammatory response when compared with other sutures like chromic catgut and polyglactin. Similar results were noted by U Hohenleutner et al (2000) where it was concluded that hypertrophy scarring was significantly high in scars sutured with polyglactin than Polydioxanone. No early wound dehiscence or infection was noted in their study with Polydioxanone as suture. In our study texture of the scar was normal like surrounding skin in 38 patients $(87.5 \%)$ giving cosmetically excellent results just comparable to the study done by U Hohenleutner et al (2000).

\section{CONCLUSIONS}

Facial trauma leads to scars which is a stigma for whole life. Meticulous suturing with use of good suture material always results in a good scar. In our experience, Polydioxanone proved to be the best buried suture which resulted in aesthetically pleasing scar with no incidence of serous discharge or stitch abscess. Though it is an expensive alternative to plain catgut or Vicryl 910, there was no pus discharge or wound infection, and hence we prefer to use this suture material as buried suture in facial injuries.

Financial or Other Competing Interests: None.

\section{REFERENCES}

[1] Watts GT. Letter: Sutures for skin closure. Lancet 1975;1 (7906):581.

[2] Beausang E, Floyd H, Dunn KW, et al. A new quantitative scale for clinical scar assessment. Plast Reconstr Surg 1988;102 (6):1954-61.

[3] Witte MB, Barbul A. General principles of wound healing. Surg Clin North Am 1997;77 (3):509-28.

[4] Moy RL, Lee A, Zalka A. Commonly used suture materials in skin surgery. Ann Fam Physician 1991;44 (6):2123-8.
[5] Ray JA, Doddi N, Regula D, et al. Polydioxanone (PDS), a novel monofilament synthetic absorbale suture. Surg Gynecol Obstet 1981;153 (4):497-507.

[6] van Zuijlen PPM, Angeles AP, Kreis RW, et al. Scar assessment tools: implications for current research. Plast Reconstr Surg 2002:109 (3):1108-22.

[7] Christopher JA, Whitaker DC, O'Donnel MJ. Cutaneous surgery ilustrated and practical approach Ist edn. New York: McGraw Hill 1982:15-26.

[8] Guyuron B, Vaughan C. A comparison of absorbable and non absorbable suture material for skin repair. Plast Reconstr Surg 1992;89 (2):234-6.

[9] Peacock EE. Wound repair. $3^{\text {rd }}$ edn. Philadelphia: WB Saunders Company 1984:15-170.

[10] Meszaros L. The right stuff a primer in closing of wounds. Dermatoligy Times 2002;23 (4):48.

[11] Qui M, Barberi A, Lee K. Facial trauma, epidemiology, demographic and fracture patterns. International Journal of Oral \& Maxillofacial Surgery 2017;46 (Suppl 1):234-5.

[12] Elarbi M. Is the etiology of facial trauma in Libya is the same as in the west. International Journal of Oral \& Maxillofacial Surg 2017;46 (Suppl 1):78-9.

[13] Gupta D, Sharma U, Chauhan S. Improved outcomes of scar revision with the use of polydioxanone suture in comparison to polyglactin 910: a randomized controlled trial. J Plast Reconstr Aesthet Surg 2018;71 (8):1159-63.

[14] Hohenleutner $U$, Egner $N$, Hohenleutner $S$, et al. Intradermal buried vertical mattress suture as sole skin closure: evaluation of 149 cases. Acta Derm Venerol 2000;80 (5):344-7.

[15] Guyuron B, Vaughan C. Comparison of polydioxanone 910 in intradermal repair. Plast Reconstr Surg 1996;98 (5):817-20.

[16] Sanz LE, Patterson JA, Kamath R, et al. Comparison if maxon suture with polyglactin, chronic caught and PDS sutures in facial closure in rats. Obstet Gynecol 1988;71 (3 Pt 1):418-22.

[17] Bhargava D, Anantanarayanan P, Prakash G, et al. Initial inflammatory response of skeletal muscle to commonly used suture materials: an animal model study to evaluate muscle healing after surgical repair-histopathological perspective. Med Oral Patol Oral Cir Bucal 2013;18 (3):491-6. 